\title{
Variation in the levels of IL-6 in pediatric patients with severe bacterial infectious diseases and correlation analysis between the levels of IL-6 and procalcitonin
}

\author{
FANGFANG BIAN, YUE-E WU and CHONG-LIN ZHANG \\ Department of Respiration, Xuzhou Children's Hospital, Xuzhou, Jiangsu 221002, P.R. China
}

Received September 28, 2016; Accepted April 3, 2017

DOI: $10.3892 /$ etm.2017.4395

\begin{abstract}
The objective of the present study was to investigate variations in the levels of interleukin (IL)-6, procalcitonin (PCT), and C-reactive protein (CRP) in children with severe bacterial infectious diseases and to analyze the correlation between the levels of IL-6 and PCT to determine the value of combined diagnosis with IL-6 and PCT. We analyzed 126 patients admitted to Xuzhou Children's Hospital for treatment, who were divided into severe bacterial infection (observation group, $\mathrm{n}=65$ ) and non-bacterial infection groups (control group, $\mathrm{n}=61$ ). The levels of IL-6, PCT, and CRP were measured and compared between the two groups. Data from both groups were statistically analyzed. The levels of IL-6,PCT, and CRT in the observation group were significantly higher than those in the control group $(\mathrm{P}<0.01)$; in the observation group, the levels of IL-6 and PCT on the 5th and 10th day after treatment were significantly lower than those before treatment $(\mathrm{P}<0.01)$; PCT showed better value for diagnosing severe bacterial infections compared with IL-6 and CRP; there was a positive correlation between the levels of IL-6 and PCT in the observation group; and the sensitivity and specificity of combined diagnosis with IL-6 and PCT for severe bacterial infection was $93.84 \%$ and $96.72 \%$, respectively, which were significantly higher than those for diagnosis with only IL-6 $(\mathrm{P}<0.01)$. In conclusion, IL-6 combined with PCT can serve as an indicator with high sensitivity for detection of severe bacterial infections in children, which is of great significance for the differential diagnosis of severe bacterial infections in the early stage.
\end{abstract}

\section{Introduction}

Severe bacterial infections can lead to the death of children. When infections progress to sepsis/severe sepsis, the mortality

Correspondence to: Dr Chong-Lin Zhang, Department of Respiration, Xuzhou Children's Hospital, 8 Sudibei Road, Xuzhou, Jiangsu 221002, P.R. China

E-mail: zhangchonglin3611@163.com

Key words: severe bacterial infection, IL-6, procalcitonin, children rate can reach $\leq 10-69 \%$ (1-4), and therefore severely threaten the health and survival of children, as has been shown in various studies. Early detection and diagnosis of severe bacterial infection as well as early effective anti-infection treatment can significantly increase the survival rate and decrease the mortality of pediatric patients, in which the key is to identify a simple but practical indicator for early diagnosis. Fifteen years ago, procalcitonin (PCT) was believed to be a highly sensitive and specific indicator for the diagnosis of sepsis (5). Interleukin (IL)-6, as an indicator of systemic inflammatory response syndrome (SIRS), is closely associated with the severity and mortality of SIRS (6). C-reactive protein (CRP) is believed to be the first acute phase reaction protein. The concentration of serum CRP can acutely increase in response to acute trauma or infection (7). Therefore, PCT, IL-6, and CRP play significant roles in the diagnosis of inflammatory diseases. In the present study, we analyzed the value of measuring the levels of PCT, IL-6, and CRP for clinical diagnosis in patients with severe bacterial infection.

\section{Patients and methods}

Patients. In the present study, we enrolled 126 pediatric patients admitted to Xuzhou Children's Hospital between April, 2014 and April, 2015. According to the introduction of the International Pediatric Sepsis Consensus Conference: Definitions for sepsis and organ dysfunction in pediatrics (2005) and Guidelines for Management of Sepsis in Pediatrics (2008), the patients were divided into severe bacterial infection (observation group, $\mathrm{n}=65$ ) and non-bacterial infection group (control group, $\mathrm{n}=61$ ), with age ranging from 2 months to 8 years. In the observation group, there were 37 males and 28 females, with average age of $1.3 \pm 0.6$ years, and weight that ranged from 5.0 to $28.2 \mathrm{~kg}$, with average weight of $9.2 \pm 1.7 \mathrm{~kg}$. In the control group, there were 35 males and 26 females, with average age of $1.3 \pm 0.8$ years, and weight that ranged from 4.5 to $29.3 \mathrm{~kg}$, with average weight of $9.4 \pm 1.6 \mathrm{~kg}$. There were no statistically significant differences in the gender ratios, age, or weight of patients in the two groups $(\mathrm{P}>0.05)$. Therefore, the data between the groups were comparable. In the observation group there were 24 patients with severe pneumonia, five with pneumonia and toxic encephalopathy, four with pneumonia and sepsis, two with pneumonia and multiple organ dysfunction syndrome 
(MODS), one with pneumonia and congenital heart disease, seven with severe encephalitis, six with suppurative tonsillitis accompanied by ardent fever, six with sepsis, two with sepsis and suppurative meningitis, four with septic shock, two with infectious diarrhea and MODS, and two with urinary tract infection. No antibiotics were taken by patients in the observation group before they were admitted to the hospital. Among the 61 patients diagnosed without bacterial infections, there were 10 patients with viral pneumonia, nine with rotavirus diarrhea, eight with viral encephalitis, five with anaphylactic purpura, five with epilepsy, five with nephrotic syndrome, three with vitamin D-deficient rickets, three with herpetic stomatitis, three with exanthema subitum, three with hand-foot-mouth disease, three with gastrointestinal disorders, two with idiopathic thrombocytopenic purpura, one with viral myocarditis, and one with breast-feeding jaundice. This study was approved by the Ethics Committee of Xuzhou Children's Hospital. Signed written informed consents were obtained from all participants before the study.

Methods. PCT and IL-6 were measured by electrochemiluminescence immunoassay using a Roche Cobas E601 module immunology analyzer (Roche, New York, NY, USA) and the matched kits for analysis of PCT and IL-6. The levels of PCT and IL- 6 were measured in venous blood collected from patients in both groups $24 \mathrm{~h}$ after admission. The criteria for positive results were set as follows: $0.5 \mathrm{ng} / \mathrm{ml}$ PCT was taken as the cut-off value of bacterial infection, i.e., levels of PCT $<0.5 \mathrm{ng} / \mathrm{ml}$ were considered negative, while levels of $\geq 0.5 \mathrm{ng} / \mathrm{ml}$ were considered positive; and a level $>2 \mathrm{ng} / \mathrm{ml}$ was the cut-off value of systemic infection. For IL-6, levels $>7 \mathrm{pg} / \mathrm{ml}$ were considered positive. The levels of PCT and IL-6 were re-assayed using blood samples collected on the 5th and 10th day after effective treatment with relevant antibiotics for patients with severe bacterial infection.

To measure CRP, we used a Siemens B-type Natriuretic Peptide assay [Siemens AG (ADR), New York, NY, USA] to perform immune-turbidimetry. CRP levels were assayed in venous blood collected from patients 24 h, 5 days, and 10 days after admission. The normal reference value ranged from 0 to $10 \mathrm{mg} / \mathrm{l}$.

Statistical analysis. SPSS 20.0 (IBM SPSS, Armonk, NY, USA) was used for data analysis. Data are presented as the mean \pm standard deviation. Independent sample t-test and paired t-test were used for statistical analyses of intergroup comparisons and the comparisons of data before and after treatment, respectively. Chi-square test was used for analyses of rates, and Pearson correlation analysis was performed for comparisons between the two factors. $\mathrm{P}<0.05$ was considered to indicate a statistically significant difference.

\section{Results}

Analysis of the levels of IL, PCT, and CRP in patients of both groups before intervention. The analysis of IL-6, PCT, and CRP of patients in both groups revealed that the levels of IL-6, PCT, and CRP in the observation group were significantly higher than those of the control group $(\mathrm{P}<0.05$; Table I).
Table I. Comparison of the levels of IL, PCT, and CRP of patients in both groups before treatment.

\begin{tabular}{lcccc}
\hline Groups & No. & $\begin{array}{c}\text { IL-6 } \\
(\mathrm{pg} / \mathrm{ml})\end{array}$ & $\begin{array}{c}\text { PCT } \\
(\mathrm{ng} / \mathrm{ml})\end{array}$ & $\begin{array}{c}\text { CRP } \\
(\mathrm{mg} / \mathrm{l})\end{array}$ \\
\hline Observation & 65 & $492.45 \pm 1,132.64$ & $27.24 \pm 30.11$ & $56.13 \pm 45.12$ \\
Control & 61 & $13.17 \pm 18.36$ & $0.31 \pm 0.42$ & $13.42 \pm 18.65$ \\
T-value & & -2.98 & 6.04 & -4.36 \\
P-value & & $<0.01$ & $<0.01$ & $<0.01$ \\
\hline
\end{tabular}

IL, interleukin; PCT, procalcitonin; CRP, C-reactive protein.

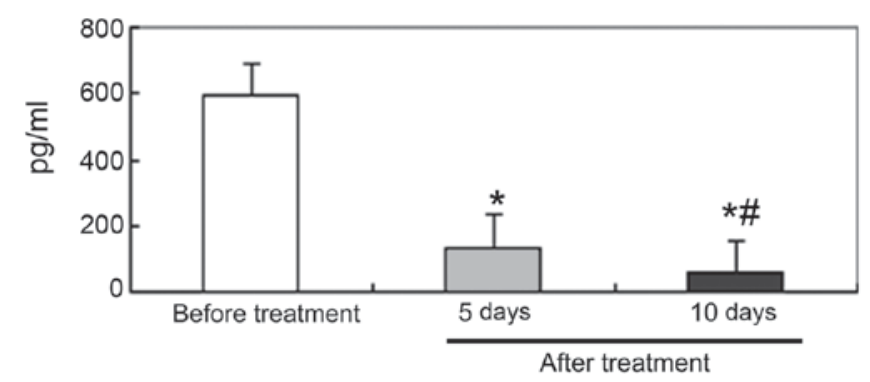

Figure 1. Comparison of the levels of IL- 6 before and after treatment in the observation group: Compared with the level before treatment, ${ }^{*} \mathrm{P}<0.01$; compared with the level on the 5th day after treatment, ${ }^{\#} \mathrm{P}<0.05$.

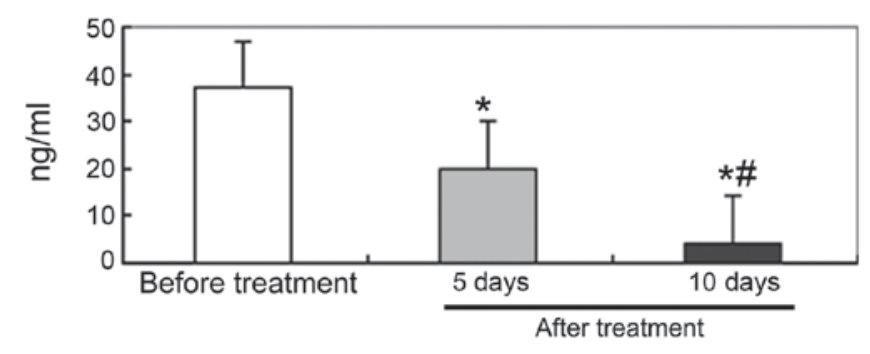

Figure 2. Comparison of the levels of PCT before and after treatment in the observation: Compared with the level before treatment, ${ }^{*} \mathrm{P}<0.01$; compared with the level on the 5 th day after treatment, ${ }^{\#} \mathrm{P}<0.05$.

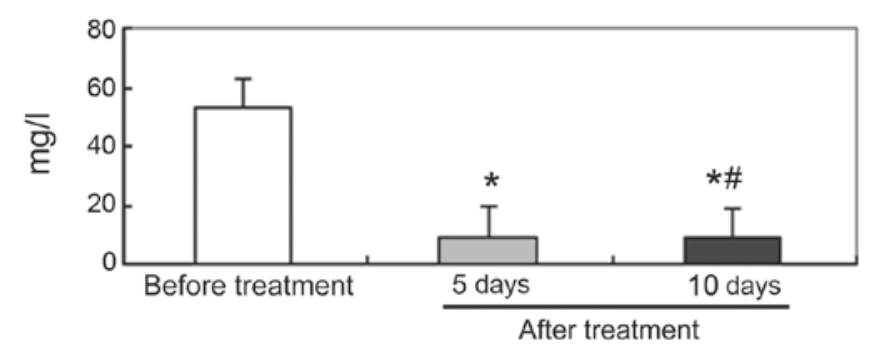

Figure 3. Comparison of the levels of CRP before and after treatment in the observation group: Compared with the level before treatment, ${ }^{*} \mathrm{P}<0.01$; compared with the level on the 5 th day after treatment, ${ }^{\#} \mathrm{P}<0.05$.

Comparisons of the levels of IL-6, PCT, and CRP of patients in the observation before and after treatment. Among the 65 patients in the observation group, three patients voluntarily left the hospital for various reasons, two patients died, and 
Table II. Correlation analysis of serum levels of PCT and IL-6 in both groups.

\begin{tabular}{lccccr}
\hline Groups & No. & IL-6 & PCT & r & P-value \\
\hline Observation & 65 & $492.45 \pm 1,132.64$ & $27.24 \pm 30.11$ & 0.681 & $<0.01$ \\
Control & 61 & $13.17 \pm 18.36$ & $0.31 \pm 0.42$ & 0.017 & $>0.05$ \\
\hline
\end{tabular}

IL, interleukin; PCT, procalcitonin.

Table III. Evaluation of the diagnostic efficiency of IL-6, PCT, and CRP (\%).

\begin{tabular}{lcrcrc}
\hline Critical values & Sensitivity & \multicolumn{1}{c}{ Specificity } & Accuracy & Positive predictive value & Negative predictive value \\
\hline PCT $>2 \mathrm{ng} / \mathrm{ml}$ & $87.69(57 / 65)$ & $91.80(56 / 61)$ & $89.68(113 / 126)$ & $91.94(60 / 62)$ & $87.50(56 / 64)$ \\
IL-6 $>60 \mathrm{pg} / \mathrm{ml}$ & $46.15^{\mathrm{a}, \mathrm{b}}(30 / 65)$ & $78.69^{\mathrm{a}, \mathrm{b}}(48 / 61)$ & $61.90^{\mathrm{a}, \mathrm{b}}(78 / 126)$ & $69.78^{\mathrm{a}, \mathrm{b}}(30 / 43)$ & $57.83^{\mathrm{a}, \mathrm{b}}(48 / 83)$ \\
CRP $>10 \mathrm{mg} / 1$ & $67.69^{\mathrm{a}}(44 / 65)$ & $73.77^{\mathrm{a}}(45 / 61)$ & $70.63^{\mathrm{a}}(89 / 126)$ & $73.33^{\mathrm{a}}(44 / 60)$ & $68.19^{\mathrm{a}}(45 / 66)$ \\
PCT+IL-6 & $93.84(61 / 65)$ & $96.72(59 / 61)$ & $95.23(120 / 126)$ & $96.83(61 / 63)$ & $93.65(59 / 63)$ \\
\hline
\end{tabular}

Compared with PCT, ${ }^{\mathrm{a}} \mathrm{P}<0.01$; compared with $\mathrm{PCT}+\mathrm{IL}-6,{ }^{\mathrm{b}} \mathrm{P}<0.05$. IL, interleukin; PCT, procalcitonin; CRP, C-reactive protein.

four patients refused to accept blood collection for re-assay. On the 5th and 10th day during treatment, 60 patients had fully recovered and discharged from the hospital. The variations in the levels of IL-6, PCT, and CRP before and after treatment were fully recorded in 56 patients.

As treatment progressed, the levels of serum IL-6 on the 5th and 10th day after treatment reached 133.21 \pm 88.54 and $57.31 \pm 28.47 \mathrm{pg} / \mathrm{ml}$, respectively, which were significantly lower than the $592.46 \pm 1,332.45 \mathrm{pg} / \mathrm{ml}$ before treatment (P<0.01; Fig. 1).

On the 5th and 10th day after treatment, the levels of serum PCT were $20.13 \pm 17.25$ and $4.32 \pm 5.40 \mathrm{ng} / \mathrm{ml}$, respectively, which were significantly lower than the $37.04 \pm 33.725 \mathrm{ng} / \mathrm{ml}$ before treatment $(\mathrm{P}<0.01 ;$ Fig. 2$)$.

On the 5th day after treatment, the levels of serum CRP were $9.24 \pm 8.86 \mathrm{mg} / \mathrm{l}$, significantly lower than the $53.13 \pm 55.17 \mathrm{mg} / \mathrm{l}$ before treatment $(\mathrm{P}<0.01)$, but not significantly different from the levels on the 10th day after treatment (Fig. 3).

Correlation analysis of the serum indicators in both groups. Pearson correlation analysis indicated that the levels of IL-6 were positively correlated with the levels of PCT in the observation group $(\mathrm{r}=0.681, \mathrm{P}<0.01)$, but there was no correlation between the levels of IL- 6 and PCT in the control group ( $\mathrm{r}=0.017, \mathrm{P}>0.05$; Table II).

Evaluation of the diagnostic efficiency of IL-6, PCT, and CRP. PCT, IL-6, and CRP levels $\geq 2 \mathrm{ng} / \mathrm{ml}, 60 \mathrm{pg} / \mathrm{ml}$, and $10 \mathrm{mg} / 1$ were set as the critical values, respectively. The sensitivity, specificity, accuracy, positive and negative predictive value of IL-6, PCT, and CRP in the clinical diagnosis of patients in the two groups are shown in Table III. In the observation group, the sensitivity, specificity, accuracy, positive predictive value, and negative predictive value of PCT for diagnosis of pediatric severe bacterial infection were higher than those of IL-6 and
CRP and the difference was statistically significant $(\mathrm{P}<0.05)$. Furthermore, the sensitivity and specificity of the diagnosis of severe bacterial infection using PCT combined with IL-6 were 93.84 and $96.72 \%$, respectively, which were significantly higher than those of diagnosis with only IL-6 $(\mathrm{P}<0.01)$.

\section{Discussion}

First identified by Weissenbach in 1980, IL-6 is a glycogen with molecular weight of $21 \mathrm{kDa}$ encoded by the IL- 6 gene. IL- 6 can bind the membrane receptor complex composed of soluble IL-6R and gp130. Generally, IL-6 is secreted by various activated cells, including T cells, B cells, NK cells and hepatocytes, and has multiple immune regulatory functions. The primary biological functions of IL-6 include: i) IL-6 can participate in the acute phase reaction by stimulating hepatocytes and inducing the synthesis of acute phase reaction proteins; ii) IL-6 can exert an antitumor effect by directly or indirectly enhancing the activity of NK cells and activating signal transduction pathways which result in activation of the NF-IL-60 transcription factor (8); iii) IL-6 can exert an immune regulatory effect by promoting the proliferation and differentiation of B cells, as well as their secretion of antibodies. In addition, IL-6 plays various important roles in hematopoiesis, regulation of metabolism, and pathogenesis of autoimmune diseases. Additionally, IL-6, as a proinflammatory cytokine, is key to initiating antibacterial inflammation, owing to its ability to activate the waterfall-like cascade reaction of inflammatory mediators, which ultimately results in multiple organ dysfunction. It was previously shown that the levels of IL-6 increase during the early stage following infection, reach peak levels $3 \mathrm{~h}$ after, and then gradually decrease in the circulation (9). It was reported that the levels of serum IL-6 were increased 2 days before the onset of clinical symptoms, and may serve as a sensitive and reliable indicator for early 
diagnosis of bacterial infection. Previously, it has been shown that not only was the increase of serum PCT observed at $2 \mathrm{~h}$ after bacterial infection, it was observed at $48 \mathrm{~h}$ (10). Increases of PCT are followed by increases of IL-6 (11). Animal experiments and clinical tests have shown that IL-6 is expressed during the course of infectious diseases, and similar to TNF- $\alpha$ and IL- $1 \beta$, is a major cytokine that results in the clinical symptoms of infectious diseases.

PCT, as an inactive calcitonin precursor encoded by a gene located on chromosome 11p15.4, is a glycoprotein composed of 116 amino acids with molecular weight of 13,000 Da and has a long half-life period (25-30 h). PCT is not influenced by hormones in the body and is stable inside and outside the body. In 1993, Assicot et al hypothesized that PCT represented a new indicator of inflammation (12). Owing to its stability, PCT could be measured in serum or plasma in the laboratory, from routinely collected blood. Currently, the double antibody sandwich immune chemiluminescence method and colorimetric method using colloidal gold are commonly used for measuring the levels of PCT. Because of the very low levels of serum PCT in healthy subjects, it is relatively undetectable (13). However, in patients with bacterial infections (such as from Gram-negative pathogens) or sepsis, the levels of serum PCT can rapidly increase during the early stage and persist for long periods. In patients with non-bacterial infections, only normal or slightly elevated levels of serum PCT are found, indicating that PCT can serve as an indicator that is specific to the inflammatory reactions caused by bacterial infections. The mechanism of action of PCT remains unclear. According to some studies, PCT may regulate inflammatory reactions by inhibiting the synthesis of inflammatory mediators (14). Animal experiments revealed that PCT can exert its effect by amplifying or aggravating the pathological course of sepsis, instead of directly participating in the initiation of sepsis (15). Various studies confirmed that increase in the levels of serum PCT are closely associated with bacterial infection (16-18). In particular, serum PCT levels can increase during the early stage of severe systemic infection, suggesting they are significant for monitoring the progression of disease, evaluating the efficacy of antibiotics, and for the judgement of prognosis. Brunkhorst et al (19) confirmed that the level of serum PCT is associated with the prognosis of infection severity in pediatric patients. Patients with neonatal sepsis with continuously stable or increased levels of serum PCT usually suffer from severe infection and have poor prognosis. However, the levels of serum PCT will decrease when the infection is controlled. In the present study, the results showed that the sensitivity and specificity of serum PCT for diagnosis were significantly higher than those of IL-6 and CRP $(\mathrm{P}<0.01)$, suggesting that serum PCT has higher efficiency for the diagnosis of severe bacterial infection. This observation was consistent with the report by Hensel et al (20). Monitoring changes in the levels of PCT has great significance for the diagnosis of bacterial infectious diseases. It can be easily and feasibly applied for their early, accurate, and sensitive diagnosis (21).

CRP, as an important indicator of the treatment course of inflammatory diseases, can be used to judge the presence of infection and determine whether a disease is in the active stage (22). Although serum CRP is frequently used for the auxiliary diagnosis of systemic inflammatory reactions, it increases slowly (only 8-12 h after the inflammatory reaction), and the concentration of CRP is regulated by the immunity of the body. Serum CRP is not suitable for the evaluation of anti-infection efficacy or prognosis because the half-life period of CRP can be recovered within a certain period after the control of inflammation. In the present study, we found that CRP showed low specificity and sensitivity for the diagnosis of severe infectious diseases, i.e., 67.69 and 73.77, respectively, which were consistent with the report by Enguix et al (23). IL-6 shows poor specificity for diagnosis despite the increased levels during the early stage of inflammation. In the present study, we found that the levels of serum IL-6, CRP, and PCT in the observation group were significantly higher than those in the control group $(\mathrm{P}<0.01)$, and there was a positive correlation between the levels of IL-6 and PCT, although the levels of IL-6, CRP, and PCT were significantly decreased after treatment $(\mathrm{P}<0.01)$. The sensitivity and specificity of IL-6 combined with PCT for the diagnosis of severe bacterial infection were $93.84 \%$ and $96.72 \%$, respectively, and were significantly higher than those for IL-6 alone $(\mathrm{P}<0.01)$, suggesting that IL-6, CRP, and PCT were highly expressed in the peripheral blood of patients with severe bacterial infections. Such pathological changes may be involved in the occurrence and progression of severe pediatric bacterial infections. Therefore, IL-6, CRP, and PCT can serve as early-warning indexes for the severity of inflammation caused by bacterial infectious diseases and as references for the judgement of prognosis. We recommend combining IL-6 with PCT for clinical detection, which demonstrates improved value for the diagnosis of bacterial infectious diseases.

\section{References}

1. da Silva ED, Koch Nogueira PC, Russo Zamataro TM, de Carvalho WB and Petrilli AS: Risk factors for death in children and adolescents with cancer and sepsis/septic shock. J Pediatr Hematol Oncol 30: 513-518, 2008.

2. Vincent JL, Sakr Y, Sprung CL, Ranieri VM, Reinhart K, Gerlach H, Moreno R, Carlet J, Le Gall JR and Payen D; Sepsis Occurrence in Acutely Ill Patients Investigators: Sepsis in European intensive care units: Results of the SOAP study. Crit Care Med 34: 344-353, 2006.

3. Leclerc F, Leteurtre S, Duhamel A, Grandbastien B, Proulx F, Martinot A, Gauvin F, Hubert P and Lacroix J: Cumulative influence of organ dysfunctions and septic state on mortality of critically ill children. Am J Respir Crit Care Med 171: 348-353, 2005.

4. Watson RS and Carcillo JA: Scope and epidemiology of pediatric sepsis. Pediatr Crit Care Med 6: S3-S5, 2005.

5. Yukioka H, Yoshida G, Kurita S and Kato N: Plasma procalcitonin in sepsis and organ failure. Ann Acad Med Singapore 30: 528-531, 2001.

6. Patel RT, Deen KI, Youngs D, Warwick J and Keighley MR: Interleukin 6 is a prognostic indicator of outcome in severe intra-abdominal sepsis. Br J Surg 81: 1306-1308, 1994.

7. Yeh ET and Willerson JT: Coming of age of C-reactive protein: Using inflammation markers in cardiology. Circulation 107: 370-371, 2003.

8. Tanaka T, Akira S, Yoshida K, Umemoto M, Yoneda Y, Shirafuji N, Fujiwara H, Suematsu S, Yoshida N and Kishimoto T: Targeted disruption of the NF-IL6 gene discloses its essential role in bacteria killing and tumor cytotoxicity by macrophages. Cell 80: 353-361, 1995.

9. Lan T, Chang L, Wu L and Yuan YF: IL-6 plays a crucial role in HBV infection. J Clin Transl Hepatol 3: 271-276, 2015.

10. Marchini G, Berggren V, Djilali-Merzoug R and Hansson LO: The birth process initiates an acute phase reaction in the fetus-newborn infant. Acta Paediatr 89: 1082-1086, 2000. 
11. Dandona P, Nix D, Wilson MF, Aljada A, Love J, Assicot M and Bohuon C: Procalcitonin increase after endotoxin injection in normal subjects. J Clin Endocrinol Metab 79: 1605-1608, 1994.

12. Assicot M, Gendrel D, Carsin H, Raymond J, Guilbaud J and Bohuon C: High serum procalcitonin concentrations in patients with sepsis and infection. Lancet 341: 515-518, 1993.

13. Casado Flores J and Blanco Quirós A: Procalcitonin. A new marker for bacterial infection. An Esp Pediatr 54: 69-73, 2001 (In Spanish).

14. Maruna P, Nedelníková K and Gürlich R: Physiology and genetics of procalcitonin. Physiol Res 49 (Suppl 1): S57-S61, 2000.

15. Whang KT, Vath SD, Becker KL, Snider RH, Nylen ES, Muller B, Li Q, Tamarkin L and White JC: Procalcitonin and proinflammatory cytokine interactions in sepsis. Shock 14: 73-78, 2000.

16. Das S, Anand D, Ray S, Bhargava S, Manocha A, Kankra M and Srivastava LM: Diagnostic accuracy of procalcitonin in proven and clinically suspected systemic infection. Crit Care 16: P6, 2012.

17. Massaro KS, Costa SF, Leone $\mathrm{C}$ and Chamone DA: Procalcitonin (PCT) and C-reactive protein (CRP) as severe systemic infection markers in febrile neutropenic adults. BMC Infect Dis 7: 137, 2007.
18. Indino P, Lemarchand P, Bady P, Torrenté AD, Genné L and Genné D: Prospective study on procalcitonin and other systemic infection markers in patients with leukocytosis. Int J Infect Dis 12: 319-324, 2008.

19. Brunkhorst FM, Heinz U and Forycki ZF: Kinetics of procalcitonin in iatrogenic sepsis. Intensive Care Med 24: 888-889, 1998.

20. Hensel M, Volk T, Döcke WD, Kern F, Tschirna D, Egerer K, Konertz W and Kox WJ: Hyperprocalcitonemia in patients with noninfectious SIRS and pulmonary dysfunction associated with cardiopulmonary bypass. Anesthesiology 89: 93-104, 1998.

21. Gambino R: C-reactive protein - undervalued, underutilized. Clin Chem 43: 2017-2018, 1997.

22. Smith RP and Lipworth BJ: C-reactive protein in simple community-acquired pneumonia. Chest 107: 1028-1031, 1995.

23. Enguix A, Rey C, Concha A, Medina A, Coto D and Diéguez MA Comparison of procalcitonin with C-reactive protein and serum amyloid for the early diagnosis of bacterial sepsis in critically ill neonates and children. Intensive Care Med 27: 211-215, 2001. 